\title{
Heavy metals from non-exhaust vehicle emissions in urban and motorway road dusts
}

\author{
Ewa Adamiec • Elżbieta Jarosz-Krzemińska • \\ Robert Wieszala
}

Received: 1 February 2016 / Accepted: 16 May 2016/Published online: 26 May 2016

(C) The Author(s) 2016. This article is published with open access at Springerlink.com

\begin{abstract}
The main sources of non-exhaust vehicular emissions that contribute to road dust are tire, brake and clutch wear, road surface wear, and other vehicle and road component degradation. This study is an attempt to identify and investigate heavy metals in urban and motorway road dusts as well as in dust from brake linings and tires. Road dust was collected from sections of the A-4 motorway in Poland, which is part of European route E40, and from urban roads in Katowice, Poland. Dust from a relatively unpolluted mountain road was collected and examined as a control sample. Selected metals $\mathrm{Cd}, \mathrm{Cr}, \mathrm{Cu}, \mathrm{Ni}, \mathrm{Pb}, \mathrm{Zn}, \mathrm{Fe}, \mathrm{Se}, \mathrm{Sr}, \mathrm{Ba}$, Ti, and $\mathrm{Pd}$ were analyzed using inductively coupled plasma-mass spectrometry, inductively coupled plasma (ICP)-optical emission spectroscopy, and atomic absorption spectroscopy on a range of size-fractionated road dust and brake lining dust $(<20,20-56,56-90,90-250$, and $>250 \mu \mathrm{m})$. The compositions of brake lining and tire dust were also investigated using scanning electron microscopyenergy-dispersive spectroscopy. To estimate the degree of potential environmental risk of non-exhaust emissions, comparison with the geochemical background and the calculations of geo-accumulation indices were
\end{abstract}

E. Adamiec $(\bowtie) \cdot$ E. Jarosz-Krzemińska

Faculty of Geology, Geophysics and Environmental Protection, AGH University of Science and Technology, Al. A. Mickiewicza 30, 30-059 Kraków, Poland

e-mail: eadamiec@agh.edu.pl

R. Wieszała

Faculty of Transport, SUT Silesian University of Technology, ul. Akademicka 2A, 44-100 Gliwice, Poland performed. The finest fractions of urban and motorway dusts were significantly contaminated with all of the investigated metals, especially with $\mathrm{Ti}, \mathrm{Cu}$, and $\mathrm{Cr}$, which are well-recognized key tracers of non-exhaust brake wear. Urban dust was, however, more contaminated than motorway dust. It was therefore concluded that brake lining and tire wear strongly contributed to the contamination of road dust.

Keywords Heavy metal · Road dust · Brake pad · Tire · Geo-accumulation index

\section{Introduction}

Heavy metals from vehicular emissions can be significant threats to humans and the environment because they have adverse effects on ecosystems inducing contamination of air, water, and soil. Dust generated during the operation of vehicles is derived from a number of sources, such as wearing of breaking systems, tires and clutch plates, erosion of the active layer of the catalytic converter, or resuspension of road dust. Mechanical and chemical weathering of pavement and shoulders, as well as windblown soil and dust from the surroundings, is considered a natural source of dust.

Recently, Gunawardana et al. (2012) have shown that road dust primarily consisted of soil-derived minerals (60\%), where $40-50 \%$ of the soil-derived minerals were quartz. The remaining amount was clay-forming minerals such as albite, microcline, chlorite, and muscovite. Organic matter from plants constituted 
approximately $2 \%$ of road dust, and the remaining amount originated from brake and tire ware, combustion emissions, and fly ash from asphalt. A sandpaper-like effect on road asphalt and bitumen can cause additional contamination because of the abrasion of white, yellow, and red paints used on roads and the grey paint and anticorrosive coatings used on guardrails.

Due to significant variability, identifying the chemical composition of road dust from vehicles is complex. The growing automotive industry and more restrictive environmental requirements have supported rapid progress in materials science development. Each year, numerous new materials are introduced into the automotive industry marketplace. More than 100 formulations of patented friction materials used in braking systems have existed since 1978 (Newman 1978). Presently, the number of materials used in braking systems is difficult to estimate. A wide variety of components are commonly used in vehicle brake lining, from steel or glass fibers and plastics that serve as reinforcements to brass chips that are used for their heat-conducting properties (Chan and Stachowiak 2004). This wide variety of materials contributes to the complexity of non-exhaust vehicle emissions.

Well-recognized sources of road dust contamination are tire wear and road surface abrasion. Detailed analyses of tire wear dust have previously been conducted by Fukuzaki et al. (1986), Fauser et al. (1999), Adachia and Tainoshob (2004), Schauer et al. (2006), and Hjortenkrans et al. (2007). These studies confirmed that significant amounts of $\mathrm{Zn}, \mathrm{Cd}, \mathrm{Co}, \mathrm{Cr}, \mathrm{Cu}, \mathrm{Hg}, \mathrm{Mo}, \mathrm{Ni}$, and $\mathrm{Pb}$ were associated with dust from tire wear. $\mathrm{Zn}$ was the most abundant heavy metal from tire wear. Its high concentrations resulted from the addition of $\mathrm{ZnO}$ and $\mathrm{ZnS}$ to the tire during vulcanization. According to Ozaki et al. (2004), tires contain approximately 1.3$1.7 \%$ Zn, but Smolders and Degryse (2002) have reported that tires contained between 0.4 and $4.3 \% \mathrm{Zn}$. Other studies have attempted to estimate emissions from tire wear and reported the emissions to range between 16 and 90 mg/tire/km (Baekken 1993; Lee et al. 1997; Legret and Pagotto 1999). The average mass of a new car tire is approximately $8 \mathrm{~kg}$, and during its lifetime, it loses up to $1.5 \mathrm{~kg}$. This means that within 3 years, $10-20 \%$ of rubber enters the environment due to abrasion. The greatest wear occurs during acceleration, braking, and cornering.

Asphalt and sandpaper-like effects are significant sources of $\mathrm{Ni}$ and As in road dust (Ozaki et al. 2004). Gadd and Kennedy (2000) have reported that the concentrations of $\mathrm{Ni}$ and $\mathrm{Zn}$ in road bitumen were higher than in raw bitumen. This suggests that heavy metal concentrations in road dust are significantly affected by vehicle operation and road abrasion. It should be noted that more tire abrasion occurs when a vehicle drives on a concrete motorway compared with an asphalt surface (Duong and Lee 2011). Driving on concrete surfaces also requires higher energy use, which results in higher fuel consumption. Higher hydrocarbon concentrations and lower heavy metal concentrations were reported from driving on asphalt. Heavy metal concentrations in road dust strongly depend on vehicle speed. As such, the highest concentrations have been recorded on motorways. Higher speeds also result in greater tire wear and increased fuel combustion. Duong and Lee (2011) compared dust from roads, where the average speed ranged from 80 to $90 \mathrm{~km} / \mathrm{h}$ with roads where the average speed ranged from 70 to $80 \mathrm{~km} / \mathrm{h}$. They have found that higher concentrations of heavy metals occurred in dust from roads that had higher average driving speeds. According to Duong and Lee (2011), the concentrations of heavy metals in road dust vary significantly depending on traffic and road features such as roundabouts, motorway roads, and traffic lights. The concentrations of metals in road dust from motorways are approximately twice those found near roundabouts and downtown areas (Duong and Lee 2011). The influence of different pavement surfaces on environmental heavy metal pollution has recently been investigated by Murphy et al. (2015).

Another source of road dust is wear from braking systems. During rapid braking, brakes are exposed to extensive heat from friction, which is transmitted to the brake discs and results in the emission of particles. The most intense brake wear occurs at intersections, corners, traffic lights, and through forced braking. According to Österle et al. 2001, standard brake linings consist of $48 \%$ barite, $14 \%$ vermiculite, $19 \%$ phenolic resin, $4.6 \%$ antimonite, $5 \%$ rubber, $6.4 \%$ aramide, and $0.3 \%$ sulfur. The composition, function, and friction testing of brake materials and their additives have been reported in detail (Blau 2001). Adachia and Tainoshob (2004) and Hjortenkrans et al. (2007) have reported that brake dust mainly contained not only $\mathrm{Fe}$, but also significant amounts of $\mathrm{Cu}, \mathrm{Sb}, \mathrm{Ba}, \mathrm{Al}, \mathrm{Si}, \mathrm{S}$, Ti, Zn, Ni, Cr, and $\mathrm{Pb}$ and a small amount of $\mathrm{Cd}$.

Exhaust emissions and their role in air quality are widely recognized (Kittelson 1998; Burtscher 2005; Maricq 2007; Ali and Athar 2008; Beelen et al. 2008; Biswas et al. 2009; Walsh 2011). The automotive 
industry has been forced to implement pollution reduction mechanisms since the European Commission established set of European guidelines about light-duty vehicles and vehicles $>3.5 \mathrm{t}$. These guidelines have led to improvements in exhaust emission control technologies, but non-exhaust particle emissions remain high. There is wide societal interest in establishing a new set of regulations for non-exhaust emissions because they are non-existent. To provide critical information about non-exhaust emissions, it is necessary to broaden existing knowledge through comprehensive research programs that focus on sources of traffic pollution such as tire wear, brake wear, road surface wear, corrosion, and resuspension of road dust. Previous studies on nonexhaust emissions are insufficient because most of them have only focused on determining metal concentrations in bulk road dust samples (Kabadayi and Cesur 2010; Guney et al. 2010; Chen et al. 2012). Only few studies have focused on the particle size distribution of road dust (e.g., Ewen et al. 2009; Grigoratos and Martini 2015; Vu et al. 2015), and Dongarrà et al. (2009) attempted to analyze brake dust in air particulate matter pollution. Additionally, there is still insufficient information about the differentiation between dusts from wearing of car parts and of geogenic origin.

The main objective of this study was to quantify heavy metal concentrations within different road dust size fractions. Research involved studying the chemical and mineralogical characteristics of urban and motorway road dusts and characterized brake lining and tire dust. Analyses of dust from wearable parts of vehicle were performed to determine the influence of these nonexhaust emission sources on the concentrations of heavy metals in road dust. Comparisons of urban and motorway dusts with mountain road dust were performed, and the geo-accumulation index $\left(I_{\text {geo }}\right)$ was calculated to evaluate the level of road dust contamination.

\section{Materials and methods}

\section{Study area}

Road dust was collected from urban roads in Katowice, Poland, on sections of the A-4 Katowice-Chorzów Batory motorway and from a relatively unpolluted mountain area in the Krowiarki Pass (Żywiecki Beskid, Poland). The sampling areas are presented in Fig. 1. The A-4 motorway is part of European route
E40, which connects to France via Belgium, Germany, Poland, the Ukraine, and Russia to the border of China.

The sampling locations were selected to minimize the impact of other non-traffic related contamination sources. They were located as far as possible from industrial plants and, in the case of the motorway, far from residential areas. Samples were collected during spring and summer to avoid the impact of other nontraffic-related pollutants, such as those emitted from household furnaces. Section of the examined A4 motorway was straight, with no more than $3 \%$ slope, approx. $30-\mathrm{m}$ width with asphalt pavement surface and curbs on each side of the road of about 15-m width. Prior sampling, there was no rainfall for 4 days and temperature during sample collection was between 19 and $24^{\circ} \mathrm{C}$. An average vehicle speed measured on the A-4 Katowice-Chorzów Batory motorway was $103 \pm 4 \mathrm{~km} / \mathrm{h}$ (cars), $92 \pm 3 \mathrm{~km} / \mathrm{h}$ (vans), $88 \pm 3 \mathrm{~km} / \mathrm{h}$ (trucks), and $89 \pm 4 \mathrm{~km} / \mathrm{h}$ (buses). An average vehicle speed in the Panewnicka-Katowice city center was approximately $35 \pm 6 \mathrm{~km} / \mathrm{h}$ for each vehicle type, and average speed in the Krowiarki Pass was approximately $56 \pm 9 \mathrm{~km} / \mathrm{h}$ for each vehicle type.

Samples of road dust, including field duplicates, were collected in situ using a vacuum cleaner specifically modified for collecting road dust.

\section{Methods}

Brake lining dust was collected in automotive repair station directly from disc and drum brake pads.

Brake lining, tire, and road dust samples were sieved into five size fractions $(<20,20-56,56-90,90-250$, and $>250 \mu \mathrm{m})$. Twenty samples of each dust type were sieved, and Student's $t$ tests were performed for comparisons.

The compositions of brake lining and tire dust were conducted in Materials Science Laboratory at the Faculty of Materials Engineering and Metallurgy, SUT Silesian University of Technology, using scanning electron microscopy (SEM) (Hitachi S4200). The experimental conditions were as follows: a $15-\mathrm{keV}$ primary electron beam, a cold cathode with field emission, and an absorption current of $1 \times 10^{-10} \mathrm{~A}$. The signal of secondary electrons was used, and magnifications from $\times 50$ to $\times 8000$ were applied for microphotography of the dust samples. An X-ray spectrometer (Voyager, NORAN (detector $\mathrm{Si}-\mathrm{Li}$, thin polymer window) for energy-dispersive spectroscopy (EDS) was used to determine the chemical composition of the dust. 


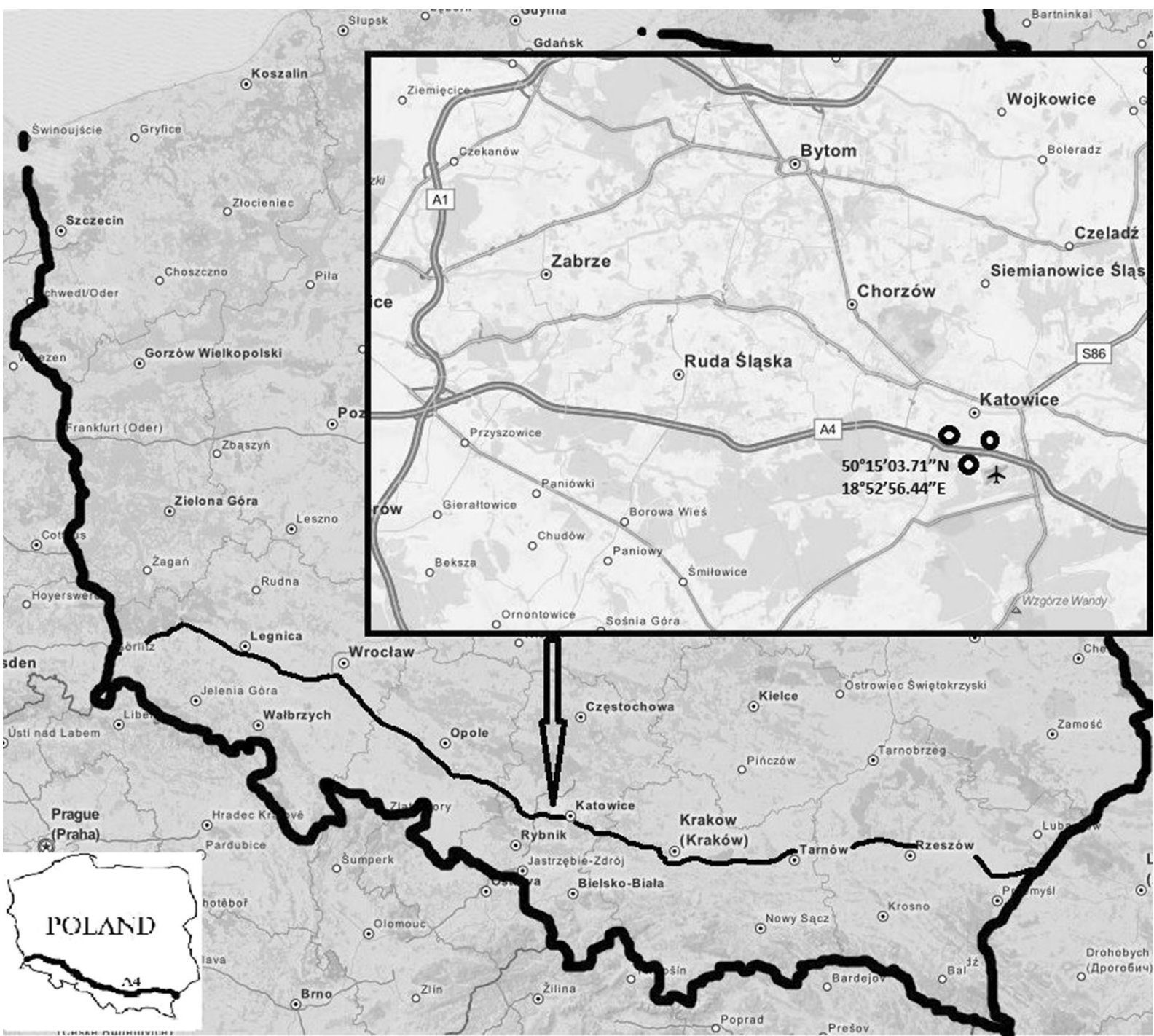

Fig. 1 Sampling locations

Metals were extracted from brake lining dust by microwave oven digestion with aqua regia, and road dust was digested according to the US EPA method 3050B (EPA 1996). Analysis was performed according to the standard certified analytical quality control procedure (PN-EN ISO 17294-1:2007) at the Faculty of Geology, Geophysics and Environmental Protection, AGH University of Science and Technology. Cd, Cr, $\mathrm{Cu}, \mathrm{Ni}, \mathrm{Pb}, \mathrm{Se}, \mathrm{Sr}, \mathrm{Zn}, \mathrm{Fe}, \mathrm{Ba}, \mathrm{Ti}$, and Pd were then quantified using inductively coupled plasma-mass spectrometry (ICP-MS) (ELAN 6100; Perkin Elmer), according to the US EPA method 6020B (EPA 1998). The concentrations of metals in road dust were then compared with the local geochemical background for
Upper Silesia based on Lis and Pasieczna (1995), and the $I_{\text {geo }}$ index was calculated according to Müller (1969). $I_{\text {geo }}$ provides information about the level of metal accumulation and was calculated from Eq. 1 (Salomons and Förstner 1984):

$I_{\text {geo }}=\log _{2} \cdot\left(\frac{C_{n}}{1.5 \cdot B n}\right)$

where $C_{n}$ is the concentration of element $n$ and $B_{n}$ is the geochemical background. 
Data quality

To obtain unambiguous and unbiased ICP-MS results, $\mathrm{Cd}, \mathrm{Cr}, \mathrm{Cu}, \mathrm{Fe}, \mathrm{Ni}, \mathrm{Se}, \mathrm{Sr}, \mathrm{Pd}, \mathrm{Ba}$, and $\mathrm{Ti}$ were also measured using inductively coupled plasma-optical emission spectroscopy (ICP-OES) (OPTIMA 7300DV; Perkin Elmer) and Fe, Zn, $\mathrm{Pb}, \mathrm{Cu}$, and $\mathrm{Cd}$ were measured using atomic absorption spectroscopy (AAS) (F-AAS Thermo Scientific IC 3500), according to US EPA method 7000 (EPA 1998) in the Laboratory of Trace Analyses at AGH University of Science and Technology. To estimate the accuracies and biases of the analytical methods, reagent blanks and certified international reference materials BCR 723 (EU JRC Institute for Reference Materials and Measurements) and METRANAL ${ }^{\mathrm{TM}} 1$ (Analytika, Czech Republic) were used to ensure that the analytical results met the required criteria. Analyses of the reference materials verified and confirmed the quality of the results. Analytical bias was statistically insignificant $(p=0.05)$, and the precisions of AAS and ICP-MS systems were satisfactory, which was verified by six different solution injections. $\mathrm{Rh}$ was used as an internal standard. Using ICP-MS, element correction equations were used for each element to minimize the impact of interferences.

\section{Results and discussion}

Characteristics of dust from brake linings and tires

Results from SEM-EDS analyses conducted on the dust fractions less than $20 \mu \mathrm{m}$ from brake linings and tires are presented in Figs. 2 and 3, respectively. Results revealed the presence of $\mathrm{Zn}, \mathrm{S}, \mathrm{Si}$, and $\mathrm{Cu}$ in tire dust and $\mathrm{Cr}, \mathrm{Fe}, \mathrm{Zn}, \mathrm{Cu}, \mathrm{Mg}, \mathrm{Al}, \mathrm{Si}, \mathrm{Zr}, \mathrm{S}$, and $\mathrm{Ca}$ in brake lining dust.

EDS analysis of brake lining dust confirmed the presence of zirconium silicate, $\mathrm{ZrSiO}_{4}$, which is a friction modifier (a filler for increasing friction resistance). Results from tire dust analyses, depicted on Fig. 3, confirmed the presence of $\mathrm{ZnO}$ and $\mathrm{ZnS}$, which are added to activate vulcanization in the tire tread.

Total concentrations of $\mathrm{Cr}, \mathrm{Zn}, \mathrm{Pb}, \mathrm{Ni}, \mathrm{Cu}, \mathrm{Ti}, \mathrm{Sr}, \mathrm{Ba}$, $\mathrm{Se}, \mathrm{Cd}, \mathrm{Fe}$, and $\mathrm{Pd}$ in bulk and size-segregated brake lining dust samples are presented in Table 1. Concentrations of the metals varied significantly within the fractions. Analysis of the bulk sample revealed that the brake dust was heavily contaminated, especially with $\mathrm{Fe}$ $(184,780 \mathrm{mg} / \mathrm{kg}), \mathrm{Ba}(20,900 \mathrm{mg} / \mathrm{kg})$, Ti $(25,400 \mathrm{mg} / \mathrm{kg})$, $\mathrm{Cu}(14,002 \mathrm{mg} / \mathrm{kg}), \mathrm{Zn}(8310 \mathrm{mg} / \mathrm{kg}), \mathrm{Pb}(2897 \mathrm{mg} / \mathrm{kg})$, and $\mathrm{Cr}(789 \mathrm{mg} / \mathrm{kg})$. The highest concentrations of investigated metals were found in the smallest fractions $(<20$ and $20-56 \mu \mathrm{m})$ of brake dust rather than in the coarser fractions (56-90 and 90-250 $\mu \mathrm{m}$ ).

\begin{tabular}{|c|c|c|c|c|c|c|c|c|c|c|c|}
\hline Weight $\%$ & $M g-K$ & $A l-K$ & $S i-K$ & $S-K$ & $\mathrm{Ca}-\mathrm{K}$ & $C r-K$ & $\mathrm{Fe}-\mathrm{K}$ & $\mathrm{Cu}-\mathrm{K}$ & $Z n-K$ & $Z r-L$ & $S n-L$ \\
\hline $1 \_2 \_p t 1$ & 4.75 & 5.51 & 13.96 & 5.81 & 0.46 & 1.01 & 5.83 & 10.66 & 4.83 & 39.73 & 7.46 \\
\hline Atom \% & $M g-K$ & $A l-K$ & $S i-K$ & $S-K$ & $C a-K$ & $C r-K$ & $\mathrm{Fe}-\mathrm{K}$ & $C u-K$ & $Z n-K$ & $Z r-L$ & $S n-L$ \\
\hline $1 \_2 \_p t 1$ & 10.00 & 10.46 & 25.46 & 9.27 & 0.59 & 0.99 & 5.34 & 8.59 & 3.78 & 22.30 & 3.22 \\
\hline
\end{tabular}

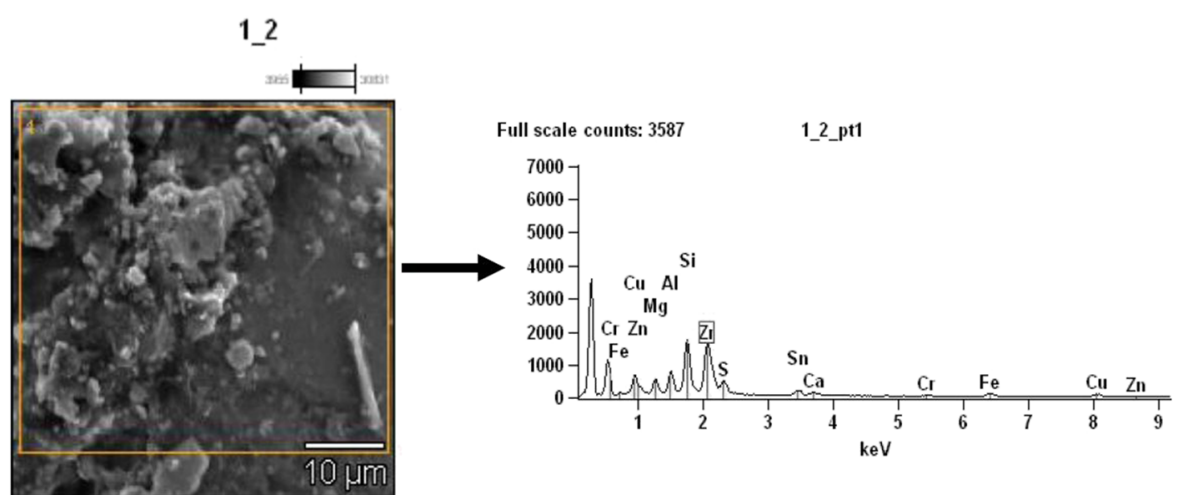

Fig. 2 Results from SEM-EDS analyses of brake lining dust smaller than $20 \mu \mathrm{m}$ in diameter (accelerating voltage $=15.0 \mathrm{kV}$; magnification $=\times 2000$ ) 
Fig. 3 Microphotograph of tire dust smaller than $20 \mu \mathrm{m}$ at magnification of $\times 1000$

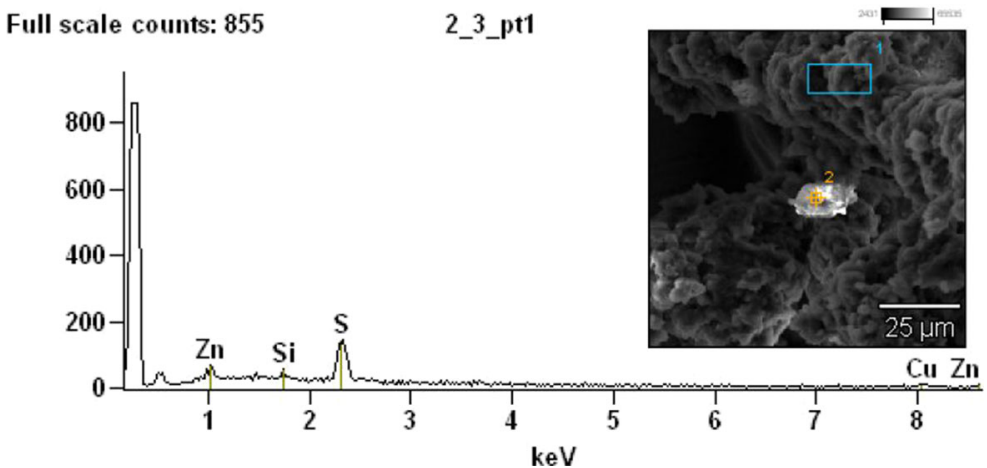

\section{Road dust characteristics}

The results from motorway and urban dusts were compared with mountain road dust, which was considered unpolluted control sample. Figures 4 and 5 present results from the qualitative chemical analysis of motorway and urban road dusts using SEM-EDS.

The concentrations of heavy metals in bulk samples of each of the examined road dust types are presented in Table 2. Urban and motorway road dust samples were highly contaminated with all of the investigated metals when compared with dust collected from the unpolluted mountain region. Urban road dust was significantly more contaminated with $\mathrm{Zn}, \mathrm{Pb}$, and $\mathrm{Cu}$ than motorway dust.

Distribution of heavy metals within road dust size fractions

Mean concentrations of metals in the five analyzed fractions are presented in Table 3. The finest fraction $(<20 \mu \mathrm{m})$ of motorway and urban dust samples was heavily contaminated with all of the investigated metals when compared with the other fractions. The $<20-\mu \mathrm{m}$ fraction of urban dust was almost twice as contaminated as motorway dust.

Concentrations of metals in the 20-56- and 56$90-\mu \mathrm{m}$ size fractions were also higher in urban dust than in motorway road dust. The greatest diversity in concentrations was found in the $90-250-\mu \mathrm{m}$ fraction for motorway and road dusts. The results revealed very high concentrations of $\mathrm{Zn}$ in the motorway and urban roads. For example, in the $<20-\mu \mathrm{m}$ fraction, the mean $\mathrm{Zn}$ concentration was $2565 \mathrm{mg} / \mathrm{kg}$ on the urban road and $1829 \mathrm{mg} / \mathrm{kg}$ on the motorway.

Both types of road dust were especially contaminated with $\mathrm{Zn}, \mathrm{Cr}, \mathrm{Cu}, \mathrm{Pb}, \mathrm{Fe}, \mathrm{Ba}$, and $\mathrm{Ti}$. On average, the dust collected from the urban area was $30 \%$ more contaminated with $\mathrm{Zn}, \mathrm{Cu}, \mathrm{Pb}$, and $\mathrm{Fe}$ than motorway dust. Motorway dust revealed $\mathrm{Ti}$ concentrations to be three times higher than those in urban dust. The concentrations of $\mathrm{Cr}, \mathrm{Ni}, \mathrm{Sr}, \mathrm{Ba}$, Se, and $\mathrm{Cd}$ in both road dust types were comparable and were significantly elevated when compared with the concentrations found in mountain road dust. Contamination with $\mathrm{Zn}$ can be attributed to the wear and tear of tires, because $\mathrm{ZnO}$ and $\mathrm{ZnS}$ are added to activate vulcanization in the tire tread. $\mathrm{Cu}$ contamination could originate from the frictional

Table 1 Concentrations of heavy metals in bulk and size-segregated brake lining dust samples

\begin{tabular}{|c|c|c|c|c|c|c|c|c|c|c|c|c|c|}
\hline Elements & Weight $\%$ & $\mathrm{Cr}$ & $\mathrm{Zn}$ & $\mathrm{Fe}$ & $\mathrm{Pb}$ & $\mathrm{Ni}$ & $\mathrm{Cu}$ & $\mathrm{Ti}$ & $\mathrm{Sr}$ & $\mathrm{Ba}$ & $\mathrm{Se}$ & $\mathrm{Cd}$ & $\mathrm{Pd}$ \\
\hline \multicolumn{14}{|c|}{ Mean concentration in brake pads dust (mg/kg) } \\
\hline Bulk sample & 100 & 789 & 8310 & 184,780 & 2897 & 369 & 14,002 & 25,400 & 156 & 20,900 & 7.88 & 2.34 & 0.082 \\
\hline \multicolumn{14}{|c|}{ Mean concentration in fraction size of brake pads dust (mg/kg) } \\
\hline$<20 \mu \mathrm{m}$ & 87.38 & 920 & 8763 & 208,099 & 2656 & 433 & 17,404 & - & 189 & - & 11.3 & 2.39 & 0.108 \\
\hline $20-56 \mu \mathrm{m}$ & 6.83 & 899 & 6728 & 199,009 & 2902 & 456 & 16,309 & - & 166 & - & 9.8 & 2.21 & 0.083 \\
\hline $56-90 \mu \mathrm{m}$ & 3.92 & 310 & 1490 & 169,950 & 928 & 56.3 & 301 & - & 20.5 & - & 1.02 & 0.98 & 0.022 \\
\hline $90-250 \mu \mathrm{m}$ & 1.87 & 87.9 & 1039 & 160,358 & 789 & 20 & 158 & - & 18.1 & - & 0.46 & 0.65 & 0.020 \\
\hline
\end{tabular}




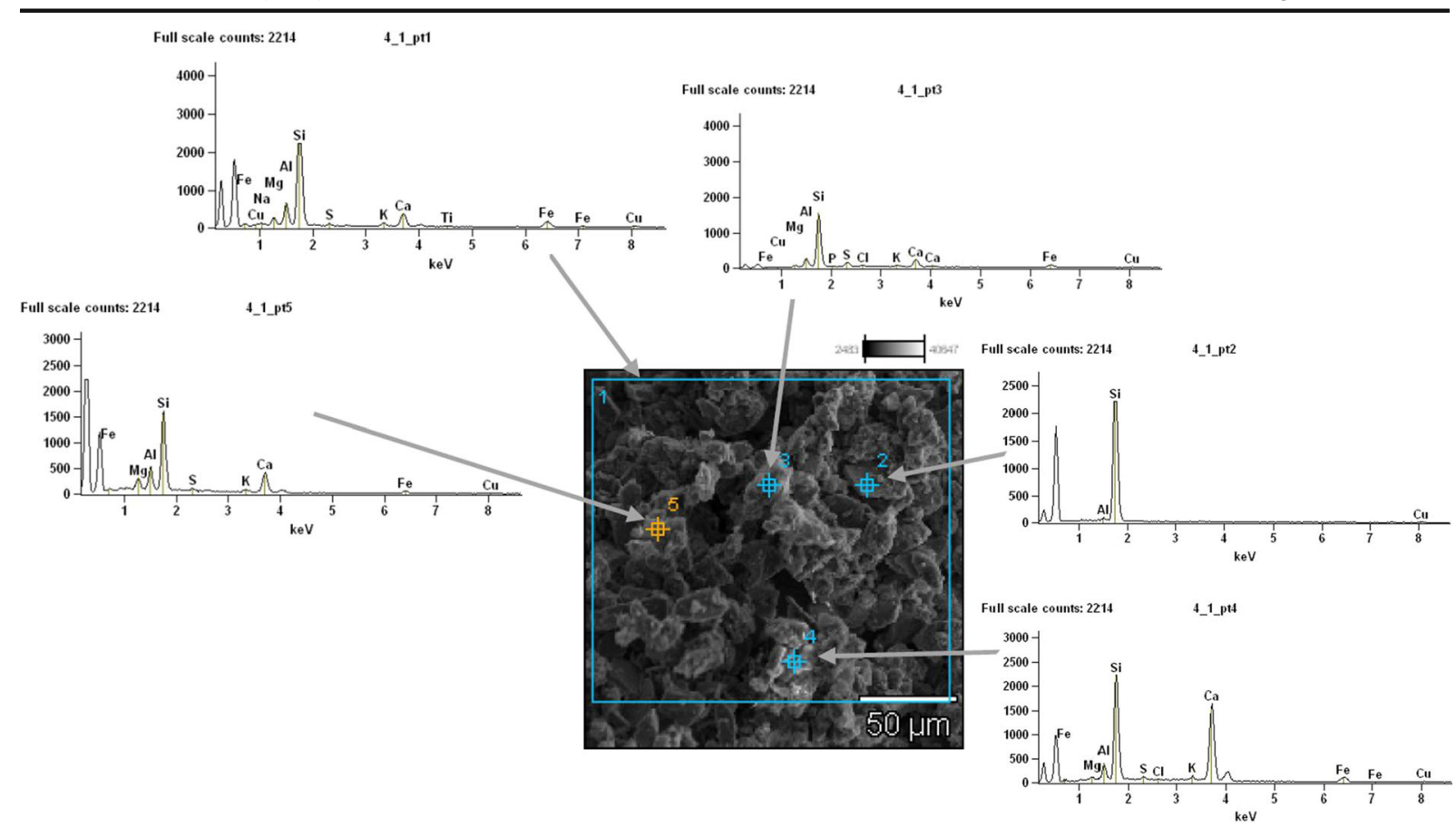

Fig. 4 SEM-EDS image of motorway road dust (accelerating voltage $=15.0 \mathrm{kV}$; magnification $=\times 500$ )

materials used in the brake system. Lead is an important component of bearing alloys, but significant concentrations of this metal in road dust could have also originated from the Silesia industrial region, which was

\begin{tabular}{|c|c|c|c|c|c|c|c|c|c|c|c|}
\hline Weight $\%$ & $M g-K$ & $A l-K$ & $S i-K$ & $S-K$ & $C l-K$ & $K-K$ & $C a-K$ & $T i-K$ & $M n-K$ & $F e-K$ & $M g-K$ \\
\hline$P_{-} 1$ & 1.7 & 7.3 & 27.5 & 1.3 & 3.1 & 2.4 & 22.7 & 20.6 & - & 13.5 & 1.7 \\
\hline$P_{-} 2$ & 0.5 & 2.9 & 61.0 & 0.9 & 0.8 & 1.9 & 5.4 & 7.9 & - & 18.8 & 0.5 \\
\hline$P_{-} 3$ & 2.6 & 4.3 & 26.6 & - & - & 2.1 & 25.6 & 22.6 & 9.3 & 6.8 & 2.6 \\
\hline$P_{-} 4$ & 0.6 & 2.0 & 65.7 & - & - & 1.4 & 12.8 & 8.2 & - & 9.3 & 0.6 \\
\hline
\end{tabular}
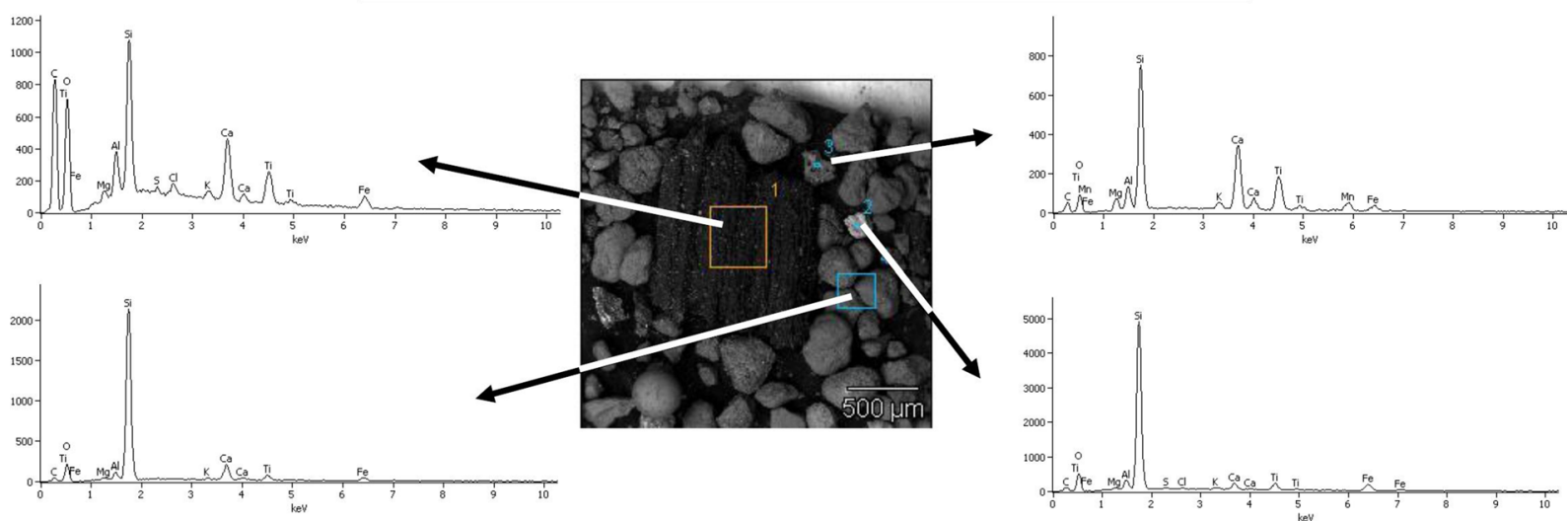

\begin{tabular}{|c|c|c|c|c|c|c|c|c|c|c|c|}
\hline Atom $\%$ & $M g-K$ & $A l-K$ & $S i-K$ & $S-K$ & $\mathrm{Cl}-\mathrm{K}$ & $K-K$ & $\mathrm{Ca}-\mathrm{K}$ & $T i-K$ & $M n-K$ & $F e-K$ & $M g-K$ \\
\hline$P_{-} I$ & 2.6 & 9.8 & 35.7 & 1.5 & 3.2 & 2.2 & 20.6 & 15.7 & - & 8.8 & 2.6 \\
\hline$P_{-} 2$ & 0.7 & 3.5 & 71.6 & 0.9 & 0.7 & 1.6 & 4.4 & 5.4 & - & 11.1 & 0.7 \\
\hline$P_{-} 3$ & 4.0 & 6.0 & 35.4 & - & - & 2.0 & 23.9 & 17.7 & 6.4 & 4.6 & 4.0 \\
\hline$P_{-} 4$ & 0.8 & 2.4 & 74.7 & - & - & 1.1 & 10.2 & 5.4 & . & 5.3 & 0.8 \\
\hline
\end{tabular}

Fig. 5 Results from SEM-EDS analyses of urban road dust (accelerating voltage $=15.0 \mathrm{kV}$; magnification $=\times 200$ ) 
Table 2 Concentrations of heavy metals in bulk samples of motorway, urban, and mountain road dusts

\begin{tabular}{|c|c|c|c|c|c|c|c|c|c|c|c|c|}
\hline Elements & $\mathrm{Cr}$ & $\mathrm{Zn}$ & $\mathrm{Fe}$ & $\mathrm{Pb}$ & $\mathrm{Ni}$ & $\mathrm{Cu}$ & $\mathrm{Ti}$ & $\mathrm{Sr}$ & $\mathrm{Ba}$ & $\mathrm{Se}$ & $\mathrm{Cd}$ & $\mathrm{Pd}$ \\
\hline \multicolumn{13}{|l|}{ Mean concentration (mg/kg) } \\
\hline Motorway dust $(n=3)$ & 232 & 1420 & 42,038 & 321 & 62.3 & 198 & 2067 & 119 & 114 & 0.078 & 0.45 & 0.033 \\
\hline Urban road dust $(n=3)$ & 211 & 2030 & 50,298 & 430 & 43.7 & 239 & 778 & 99.8 & 192 & 0.059 & 0.352 & 0.031 \\
\hline Mountain road $(n=1)$ & 34.2 & 211 & 13,467 & 24.2 & 29.6 & 78.4 & 309 & 99.5 & 87.7 & 0.02 & 0.12 & 0.015 \\
\hline
\end{tabular}

located nearby. Until recently, lead was also used as a material for wheel balancing weights, but it has been replaced by zinc weights. It should be, however, noted that $\mathrm{Pb}$ is very persistent element and its elevated concentration in urban dust could also be a consequence of common use of $\mathrm{PbO}_{4}$ as gasoline additive in Poland up to March 2005. Contamination of road dust with chromium is the result of adding it as a main component to alloys used to produce wrist pins and connecting rods. An elevated amount of $\mathrm{Ba}$ in urban dust could be a consequence of using $\mathrm{BaSO}_{4}$ for improving wear resistance.

Concentrations of metals in the studied road dust were then used to calculate the $I_{\text {geo }}$ accumulation index (Müller 1969), and the results are presented in Figs. 6 and 7.
Road dust contamination level was estimated based on $I_{\text {geo }}$ index calculation. It was concluded that the finest fractions of motorway road dust $(<20$ and $20-56 \mu \mathrm{m})$ were extremely contaminated with Ti (class 6); strongly contaminated with $\mathrm{Cr}, \mathrm{Ni}$, and $\mathrm{Cu}$ (class 4); and moderately contaminated with $\mathrm{Zn}$ (class 2 ). As per the contamination with the remaining metals $(\mathrm{Fe}, \mathrm{Pb}, \mathrm{Ba})$, the finest fractions of road dust were classified between 1 and $3 I_{\text {geo }}$ class (Fig. 7, Table 3). Furthermore, Ti concentration in motorway road dust (finest fractions) exceeds up to 1000 times the local background value for Upper Silesia region (according to Geochemical Atlas of Poland).

Calculation of $I_{\text {geo }}$ index for urban road dust revealed that its finest fractions are strongly to extremely contaminated with $\mathrm{Cu}, \mathrm{Cr}$, and $\mathrm{Ti}$ (class 5) and strongly

Table 3 Concentrations of heavy metals in the different size fractions of urban, motorway, and mountain road dusts

\begin{tabular}{|c|c|c|c|c|c|c|c|c|c|c|c|c|c|}
\hline Mean concentration in fractions & Weight $\%$ & $\mathrm{Cr}$ & $\mathrm{Zn}$ & $\mathrm{Fe}$ & $\mathrm{Pb}$ & $\mathrm{Ni}$ & $\mathrm{Cu}$ & $\mathrm{Ti}$ & $\mathrm{Sr}$ & $\mathrm{Ba}$ & $\mathrm{Se}$ & $\mathrm{Cd}$ & $\mathrm{Pd}$ \\
\hline \multicolumn{14}{|l|}{ Motorway dust $\mathrm{mg} / \mathrm{kg}(n=3)$} \\
\hline$<20 \mu \mathrm{m}$ & 0.86 & 182 & 1829 & 51,907 & 456 & 109 & 287 & 2678 & 132 & 533 & 0.157 & 0.912 & 0.095 \\
\hline $20-56 \mu \mathrm{m}$ & 1.58 & 132 & 1609 & 50,899 & 362 & 98.2 & 209 & 2289 & 129 & 302 & 0.109 & 0.659 & 0.087 \\
\hline $56-90 \mu \mathrm{m}$ & 2.86 & 112 & 1390 & 46,758 & 326 & 87 & 120 & 1198 & 113 & 256 & 0.043 & 0.584 & 0.029 \\
\hline $90-250 \mu \mathrm{m}$ & 25.72 & 109 & 593 & 30,145 & 213 & 49.9 & 93.2 & 399 & 108 & 99.8 & 0.056 & 0.245 & 0.023 \\
\hline$>250 \mu \mathrm{m}$ & 68.98 & 111 & 730 & 19,940 & 138 & 48.2 & 78.2 & 422 & 109 & 107 & 0.053 & 0.098 & 0.019 \\
\hline \multicolumn{14}{|l|}{ Urban road dust $\mathrm{mg} / \mathrm{kg}(n=3)$} \\
\hline$<20 \mu \mathrm{m}^{\mathrm{a}}$ & 0.94 & 219 & 2565 & 62,897 & 789 & 87.9 & 389 & 863 & 129 & 509 & 0.161 & 1.094 & 0.101 \\
\hline $20-56 \mu \mathrm{m}$ & 2.98 & 198 & 2267 & 54,389 & 743 & 89.4 & 353 & 809 & 98.2 & 312 & 0.086 & 0.78 & 0.089 \\
\hline $56-90 \mu \mathrm{m}$ & 6.87 & 169 & 1768 & 50,980 & 569 & 76.5 & 189 & 609 & 95.3 & 267 & 0.034 & 0.56 & 0.044 \\
\hline $90-250 \mu \mathrm{m}$ & 32.98 & 222 & 1879 & 41,434 & 309 & 28.4 & 103 & 189 & 66.5 & 109 & 0.029 & 0.218 & 0.034 \\
\hline$>250 \mu \mathrm{m}$ & 56.23 & 87.9 & 946 & 20,390 & 387 & 22.7 & 89 & 176 & 89.4 & 201 & 0.022 & 0.081 & 0.022 \\
\hline \multicolumn{14}{|l|}{ Mountain road dust $\mathrm{mg} / \mathrm{kg}(n=1)$} \\
\hline $20-56 \mu \mathrm{m}$ & 0.54 & 51.7 & 559 & 14,098 & 188 & 54.8 & 209 & 498 & 87.3 & 161 & 0.032 & 0.192 & 0.016 \\
\hline $56-90 \mu \mathrm{m}$ & 1.41 & 48.3 & 396 & 13,077 & 40.9 & 42.2 & 86.4 & 308 & 78.1 & 113 & 0.019 & 0.147 & 0.015 \\
\hline $90-250 \mu \mathrm{m}$ & 28.31 & 23.9 & 221 & 12,900 & 47.6 & 28.1 & 35.3 & 297 & 79.4 & 79.9 & 0.028 & 0.111 & 0.013 \\
\hline$>250 \mu \mathrm{m}$ & 69.74 & 38.9 & 198 & 10,890 & 12.4 & 23.3 & 33.9 & 288 & 134 & 89.9 & b.d.l. & 0.198 & 0.015 \\
\hline
\end{tabular}

b.d.l. below detection limit

${ }^{\mathrm{a}} n=1$ 


\begin{tabular}{|l|c|c|c|c|c|c|c|c|c|c|c|}
\hline Metal/fractions & $\mathrm{Cr}$ & $\mathrm{Zn}$ & $\mathrm{Fe}$ & $\mathrm{Pb}$ & $\mathrm{Ni}$ & $\mathrm{Cu}$ & $\mathrm{Ti}$ & $\mathrm{Ba}$ & $\mathrm{Cd}$ \\
\hline \multicolumn{9}{|c|}{ I geo index } \\
\hline Motorway dust $(\mathrm{n}=3)$ & 5 & 3 & 3 & 3 & 4 & 5 & 6 & 1 & 0 \\
\hline Urban road dust $(\mathrm{n}=3)$ & 5 & 4 & 3 & 3 & 3 & 5 & 5 & 2 & 0 \\
\hline Mountain road $(\mathrm{n}=1)$ & 3 & 1 & 1 & 0 & 3 & 3 & 3 & 1 & 0 \\
\hline Background* $(\mathrm{mg} / \mathrm{kg})$ & 5 & 121 & 5600 & 53 & 4 & 7 & 27 & 54 & 1,4 \\
\hline
\end{tabular}

* Local background values (geometrical mean) for bulk soil according to Lis, Pasieczna (1995)

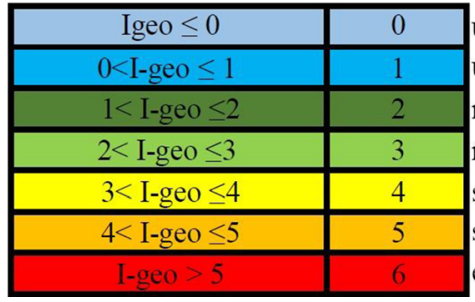

Fig. $6 I_{\text {geo }}$ calculation for road dust (bulk samples)

contaminated with $\mathrm{Zn}, \mathrm{Ni}$, and $\mathrm{Pb}$ (classes 3-4). Both road and urban dusts were not contaminated with $\mathrm{Cd}$ meeting class 0 according to $I_{\text {geo }}$.
Detailed results of road dust analysis revealed that the finest fraction of both types of dust were the most contaminated ones (Fig. 7, Table 3). Contamination of

\begin{tabular}{|c|c|c|c|c|c|c|c|c|c|}
\hline Metal/fractions & $\mathrm{Cr}$ & $\mathrm{Zn}$ & $\mathrm{Fe}$ & $\mathrm{Pb}$ & $\mathrm{Ni}$ & $\mathrm{Cu}$ & $\mathrm{Ti}$ & $\mathrm{Ba}$ & $\mathrm{Cd}$ \\
\hline \multicolumn{10}{|c|}{ I geo (Motorway) } \\
\hline$<20 \mu \mathrm{m}$ & 5 & 2 & 3 & 2 & 4 & 4 & 6 & 3 & 0 \\
\hline $20-56 \mu \mathrm{m}$ & 4 & 2 & 3 & 1 & 4 & 4 & 6 & 2 & 0 \\
\hline $56-90 \mu \mathrm{m}$ & 4 & 2 & 3 & 1 & 4 & 3 & 5 & 2 & 0 \\
\hline $90-250 \mu \mathrm{m}$ & 4 & 1 & 2 & 1 & 3 & 3 & 3 & 1 & 0 \\
\hline$>250 \mu \mathrm{m}$ & 4 & 1 & 1 & 0 & 3 & 3 & 4 & 1 & 0 \\
\hline \multicolumn{10}{|c|}{ I geo (Urban road) } \\
\hline$<20 \mu \mathrm{m}$ & 5 & 3 & 3 & 3 & 4 & 5 & 5 & 3 & 0 \\
\hline $20-56 \mu \mathrm{m}$ & 5 & 3 & 3 & 2 & 4 & 5 & 4 & 2 & 0 \\
\hline $56-90 \mu \mathrm{m}$ & 5 & 2 & 3 & 2 & 4 & 4 & 4 & 2 & 0 \\
\hline $90-250 \mu \mathrm{m}$ & 5 & 2 & & 1 & 2 & 3 & 2 & 1 & 0 \\
\hline$>250 \mu \mathrm{m}$ & 4 & 1 & 1 & 1 & 2 & 3 & 2 & 2 & 0 \\
\hline \multicolumn{10}{|c|}{ I geo (Mountain road) } \\
\hline $20-56 \mu \mathrm{m}$ & 3 & 1 & 1 & 0 & 3 & 4 & 4 & 1 & 0 \\
\hline $56-90 \mu \mathrm{m}$ & 3 & 0 & 1 & 0 & 3 & 4 & 3 & 1 & 0 \\
\hline $90-250 \mu \mathrm{m}$ & 2 & 0 & 1 & 0 & 2 & 1 & 3 & 0 & 0 \\
\hline$>250 \mu \mathrm{m}$ & 3 & 0 & 0 & 0 & 2 & 1 & 3 & 1 & 0 \\
\hline Background* (mg/kg) & 5 & 121 & 5600 & 53 & 4 & 7 & 27 & 54 & 1,4 \\
\hline
\end{tabular}

* Local background values (geometrical mean) for bulk soil according to Lis, Pasieczna (1995 )

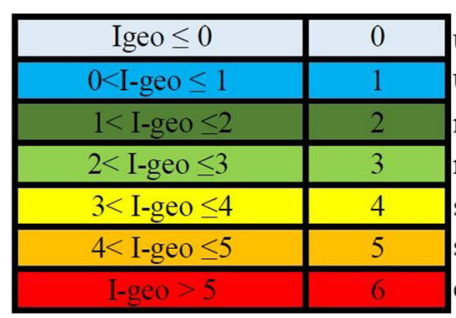

unpolluted

unpolluted to moderately polluted

moderately polluted

moderately to strongly polluted

strongly polluted

strongly to extremely polluted

extremely polluted

Fig. $7 I_{\text {geo }}$ calculation for selected road dust size fractions 
the fraction less than $20 \mu \mathrm{m}$ is likely a consequence of clay minerals present in the surrounding soil, but heavy metals in this fraction can also originate from dust derived from brake lining wear.

\section{Conclusions}

Bulk samples and the finest fractions of urban and motorway dusts (up to $56 \mu \mathrm{m}$ ) were significantly contaminated with all of the investigated metals, in particular with $\mathrm{Ti}, \mathrm{Cu}, \mathrm{Cr}, \mathrm{Ni}, \mathrm{Zn}, \mathrm{Fe}, \mathrm{Pb}$, and $\mathrm{Ba}$. Since Ti, $\mathrm{Cu}$, and $\mathrm{Cr}$ are well-recognized key tracers of nonexhaust brake wear emissions, high concentrations of these metals confirm that brake wear highly contributes to road dust contamination. Elevated concentration of $\mathrm{Ti}$ in both motorway and urban road dusts is undoubtedly of anthropogenic origin, and it might be linked to the use of alkali metal titanates as inorganic fillers for the purpose of stabilizing friction coefficient. Furthermore, contamination of road dust with copper is probably due to using it as a component of reinforcing fiber, which in form of chips or granules, combined with $\mathrm{Zn}$, improves toughness and strength of brake pads.

The fine fraction of urban dust is more contaminated than the motorway dust. This is due to different driving conditions on urban roads and motorways. In the city, there is much more braking involved, what causes additional contamination of road dust with brake pads wear. Moreover, limited or poor air circulation in the city causes that resuspension of road dust occurs more likely. Sieve analysis of brake lining dust and tire dust did not reveal particles with diameters greater than $250 \mu \mathrm{m}$. From this, we have concluded that the fraction $>250 \mu \mathrm{m}$ in road dust was of geogenic origin and was not related to the dust from braking systems. High $\mathrm{Zn}$ concentrations in the coarse fraction $(>250 \mu \mathrm{m})$ were likely the result of tire abrasion. This conclusion is in line with the findings of Gunawardana et al. (2012), who stated that even though individual $\mathrm{ZnO}$ particles are, on average, no bigger than $65 \mu \mathrm{m}$, in reality, they form agglomerates 1000-2000 $\mu \mathrm{m}$ in diameter. It should also be noted that the fine fraction can agglomerate with coarse fraction in other cases as well.

Particles $<56 \mu \mathrm{m}$ from brake linings and tire dust should be considered an indicator of heavy metal pollution because over $90 \%$ of these metals are found in the fine fraction. Attention should also be drawn to the fact that significant sources of metals in the finest fractions of road dust could also be of geogenic origin.

On the mountain road, where traffic is significantly less intensive, vehicles had practically no influence on the level of dust contamination. Confirming this, the concentration of $\mathrm{Pd}$, which comes from catalytic converters in vehicles, in mountain road dust was much lower in the finest fraction, when compared with motorway and urban dusts. Considering the geochemical background levels and $I_{\text {geo, }}$, it can be assumed that $\mathrm{Cr}$, $\mathrm{Zn}, \mathrm{Pb}$, and $\mathrm{Cu}$, which were detected in both types of road dust, pose a significant hazard to the environment.

Monitoring of the fine fraction of road dust should be intensified since this fraction easily enters the environment and human airways. Processes such as resuspension of road dust and exhaust and non-exhaust car emission mostly affect children or babies in strollers, because the highest concentrations occur low to the ground. It would also be valuable to determine speciation of different metals in urban and motorway dusts to better understand the health risks that they pose. Further studies on the impact of traffic-related emissions on human health should also be considered. The obtained results can furthermore be used for cost-benefit analyses.

Acknowledgments This research was supported by the AGH University of Science and Technology in Krakow as research project no. 11.11.140.199 and Polish-Norwegian Research Programme operated by the National Centre for Research and Development under the Norwegian Financial Mechanism 2009-2014 in the frame of Project Contract No Pol-Nor/208849/106/2015.

Open Access This article is distributed under the terms of the Creative Commons Attribution 4.0 International License (http://creativecommons.org/licenses/by/4.0/), which permits unrestricted use, distribution, and reproduction in any medium, provided you give appropriate credit to the original author(s) and the source, provide a link to the Creative Commons license, and indicate if changes were made.

\section{References}

Adachia, K., \& Tainoshob, Y. (2004). Characterization of heavy metal particles embedded in tire dust. Environment International, 30, 1009-1017.

Ali, M., \& Athar, M. (2008). Air pollution due to traffic, air quality monitoring along three sections of National Highway N-5, Pakistan. Environmental Monitoring and Assessment, 136, 219-226.

Baekken, T. (1993). Environmental effects of asphalt and tyre wear by road traffic. Nordic seminar og Arbejdsrapporter 1992:628, Copenhagen, Denmark. 
Beelen, R., Hoek, G., Brandt, P. A., Goldbohmn, R. A., Fischer, P., Schouten, L. J., Jerrett, M., Hughes, E., Armstrong, B., \& Brunekreef, B. (2008). Long-term effects of traffic-related air pollution on mortality in a Dutch cohort (NLCS-AIR Study). Environmental Health Perspectives, 116(2), 196-202.

Biswas, S., Verma, V., Schauer, J. J., \& Sioutas, C. (2009). Chemical speciation of PM emissions from heavy-duty diesel vehicles equipped with diesel particulate filter (DPF) and selective catalytic reduction (SCR) retrofits. Atmospheric Environment, 43, 1917-1925.

Blau P. (2001). Compositions, functions, and testing of friction brake materials and their additives. Oak Ridge National Laboratory UT-Battelle, Report ORNL/M-5824 for U.S. Department of Energy, 3-24.

Burtscher, H. (2005). Physical characterization of particulate emissions from diesel engines: a review. Aerosol Science, 36, 896-932.

Chan, D., \& Stachowiak, G. W. (2004). Review of automotive brake friction materials. Proceedings of the Institution of Mechanical Engineers, 218, 953-965.

Chen, J., Wang, W., Liu, H., \& Ren, L. (2012). Determination of road dust loadings and chemical characteristics using resuspension. Environmental Monitoring and Assessment, 184, 1693-1709.

Dongarrà, G., Manno, E., \& Varrica, D. (2009). Possible markers of traffic-related emissions. Environmental Monitoring and Assessment, 154, 117-125.

Duong, T., \& Lee, B. K. (2011). Determining contamination level of heavy metals in road dust from busy traffic areas with different characteristics. Journal of Environmental Management, 92(3), 554-562.

EPA (1996). Method 3050B: acid digestion of sediments, sludges, and soils. Revision 2.

EPA (1998). Method 6020B: inductively coupled plasma-mass spectrometry. Revision 2

Ewen, C., Anagnostopoulou, M. A., \& Ward, N. L. (2009). Monitoring of heavy metal levels in roadside dusts of Thessaloniki, Greece in relation to motor vehicle traffic density and flow. Environmental Monitoring and Assessment, 157, 483-498.

Fauser, P., Tjell, J. C., Mosbaek, H., \& Pilegaard, K. (1999). Quantification of tire-tread particles using extractable organic zinc as tracer. Rubber Chemical Technology, 72, 969-977.

Fukuzaki, N., Yanaka, T., \& Urushiyama, Y. (1986). Effects of studded tires on roadside airborne dust pollution in Niigata, Japan. Atmospheric Environment, 20, 377-386.

Gadd J., \& Kennedy P. (2000). Preliminary examination of organic compounds present in tyres, brake pads and road bitumen in New Zealand: prepared for the Ministry of Transport by Kingett Mitchell Limited.

Grigoratos, T., \& Martini, G. (2015). Brake emissions: review. Environmental Science and Pollution Research, 22, 24912504.

Gunawardana, C., Goonetilleke, A., Egodawatta, P., Dawes, L., \& Kokot, S. (2012). Source characterization of road dust based on chemical and mineralogical composition. Chemosphere, 87, 163-170.
Guney, M., Onay, T. T., \& Copty, N. K. (2010). Impact of overland traffic on heavy metal levels in highway dust and soil of Istanbul, Turkey. Environmental Monitoring and Assessment, 164, 101-110.

Hjortenkrans, D. S. T., Bergbäck, B. G., \& Häggerud, A. V. (2007). Metal emissions from brake linings and tires: case studies of Stockholm, Sweden 1995/1998 and 2005. Environmental Science \& Technology, 41, 5224-5230.

Kabadayi, F., \& Cesur, H. (2010). Determination of $\mathrm{Cu}, \mathrm{Pb}, \mathrm{Zn}$, $\mathrm{Ni}, \mathrm{Co}, \mathrm{Cd}$, and $\mathrm{Mn}$ in road dust of Samsun City. Environmental Monitoring and Assessment, 168, 241-253.

Kittelson, D. B. (1998). Engines and nanoparticles: a review. Journal of Aerosol Science, 29(5-6), 575-588.

Lee, P. K., Touray, J. C., Baillif, P., \& Ildefonse, J. P. (1997). Heavy metal contamination of settling particles in a retention pond along the A-71 motorway in Sologne, France. The Science of the Total Environment, 201, 1-15.

Legret, M., \& Pagotto, C. (1999). Evaluation of pollutant loadings in the runoff waters from a major rural highway. The Science of the Total Environment, 235, 143-150.

Lis J., \& Pasieczna A. (1995). Geochemical atlas of Upper Silesia, Wydawnictwo Kartograficzne Polskiej Agencji Ekologicznej S.A., Warszawa.

Maricq, M. M. (2007). Chemical characterization of particulate emissions from diesel engines: a review. Journal of Aerosol Science, 38, 1079-1118.

Müller, G. (1969). Index of geo accumulation in sediments of the Rhine River. Geology Journal, 2, 109-118.

Murphy, L. U., Cochrane, T. A., \& O'Sullivan, A. (2015). The influence of different pavement surfaces on atmospheric copper, lead, zinc, and suspended solids attenuation and wash-off. Water, Air, \& Soil Pollution, 226, 232. doi:10. 1007/s11270-015-2487-2.

Newman, L. B. (1978). Friction materials—recent advances. Park Ridge, NJ: Noyes Data Corporation.

Österle, W., Griepentrog, M., Gross, T., \& Urban, I. (2001). Chemical and microstructural changes induced by friction and wear of brakes. Wear, 251, 1469-1476.

Ozaki, H., Watanabe, I., \& Kuno, K. (2004). Investigation of the heavy metal sources in relation to automobiles. Water, Air, and Soil Pollution, 157, 209-223.

Salomons, W., \& Förstner, U. (1984). Metals in the hydrocycle. Verlag: Springer.

Schauer, J. J., Lough, G. C., Shafer, M. M., Christensen, W. F., Arndt, M. F., DeMinter, J. T., \& Park, J. S. (2006). Characterization of metals emitted from motor vehicles. Research Report. Health Effects Institute, 133, 1-76. discussion 77-88.

Smolders, E., \& Degryse, F. (2002). Fate and effect of zinc from tire debris in soil. Environmental Science \& Technology, 36, 3706-3710.

Vu, T. V., Delgado-Saborit, J. M., \& Harrison, R. M. (2015). Review: particle number size distributions from seven major sources and implications for source apportionment studies. Atmospheric Environment, 122, 114-132.

Walsh MP (2011). Mobile source related air pollution: effects on health and the environment. Encyclopedia of Environmental Health. 